\title{
Pengaruh Rasio Hutang Terhadap Profitabilitas (Studi Pada Perusahaan Properti \& Real Estate Terdaftar di Bursa Efek Indonesia Periode 2020)
}

\author{
Received: \\ 23 Agustus 2021 \\ Revision \\ Robii'ah Alma'uunah* dan Mukaram \\ Jurusan Administrasi Niaga, Politeknik Negeri Bandung, Indonesia
}

received:

28 Agustus 2021

Accepted:

4 Agustus 2021

\begin{abstract}
:
The characteristics of the property as a product that does not depreciate raises speculation that property as a product will not end up as consumption, but an investment. However, sales that occur are not automatically recognized in the recording of financial statements after the application of PSAK 72. The application of PSAK 72 will at least affect the profits and debt levels of property companies because sales that have not been recognized will be included as current liabilities. In this study, the GPM (gross profit margin) ratio is used to determine the profit margin, ROA (return on assets) to determine the return on investment, and DR (debt ratio) to determine the amount of debt to total funding. The research methods used in this study include descriptive analysis, regression analysis, coefficient of determination analysis, and hypothesis testing. The results showed that debt ratio has a negative effect on profitability.
\end{abstract}

Keywords: debt, profit, property

\begin{abstract}
Abstrak:
Karakteristik properti sebagai produk yang tidak mengalami depresiasi menimbulkan spekulasi bahwa properti sebagai produk tidak akan berakhir sebagai konsumsi, melainkan investasi. Namun, penjualan yang terjadi tidak serta merta dapat diakui secara pencatatan laporan keuangan setelah diterapkannnya PSAK 72. Penerapan PSAK 72 setidaknya akan mempengaruhi keuntungan dan tingkat hutang pada perusahaan properti karena penjualan yang belum bisa diakui akan termasuk sebagai hutang lancar. Pada penelitian ini digunakan rasio GPM (gross profit margin) untuk mengetahui marjin keuntungan, ROA (return on asset) untuk mengetahui nilai pengembalian atas investasi, dan DR (debt ratio) untuk mengetahui besaran hutang terhadap total pendanaan. Adapun metode penelitian yang dipakai dalam penelitian ini diantaranya berupa analisis deskriptif, analisis regresi, analisis koefisien determinasi, dan uji hipotesis. Hasil penelitian menunjukkan bahwa rasio hutang memiliki pengaruh negatif terhadap profitabilitas.
\end{abstract}

Kata kunci: hutang, keuntungan, properti

\section{Pendahuluan}

Berdasarkan Survei Harga Properti Residensial diketahui penjualan rumah mengalami perbaikan pada kuartal-2 tahun 2020 seiring dengan adanya penurunan suku bunga Kredit Pemilikan Rumah (KPR), sedangkan berdasarkan Perkembangan Properti Komersial, permintaan pada properti komersial terindikasi mulai mengalami perbaikan pada kuartal-3 tahun 2020. Karakteristik properti sebagai produk yang tidak mengalami depresiasi menimbulkan spekulasi bahwa pembelian pada instrumen tersebut tidak akan berakhir sebagai konsumsi, melainkan investasi (Departemen Statistik BI, 2020b, 2020a). Penjualan dan permintaan yang mulai mengalami perbaikan pada kuartal 2 dan 3 
mengindikasikan adanya perbaikan perolehan laba pada emiten sektor properti dan real estate, namun penjualan yang terjadi tidak serta merta dapat diakui secara pencatatan laporan keuangan setelah diterapkannnya PSAK 72 pada tahun 2020. Adapun penerapan aturan tersebut juga mempengaruhi pencatatan persediaan, liabilitas jangka pendek, dan saldo laba.

Perusahaan sektor properti identik dengan keperluan dana yang besar untuk melakukan pembangunan, terlebih proses unit properti untuk dapat dipasarkan memakan waktu yang cukup lama. Diantaranya telah memiliki izin mendirikan bangunan (IMB) dan setidaknya bangunan mencapai $20 \%$ tahap pengerjaan, sehingga membuat banyak perusahaan sektor properti tidak bisa hanya mengandalkan modal sendiri. Hal tersebut agaknya sesuai dengan yang dikatakan oleh Puspitasari dkk (2020)bahwa pentingnya hutang bagi kelangsungan aktivitas perusahaan sektor properti menimbulkan asumsi terdapat hubungan yang signifikan dan positif bagi tingkat pengembalian atas investasi atau profitabilitas, hasil ini disinyalir karena properti sebagai produk memiliki jaminan yang nilainya akan terus meningkat seiring dengan pertambahan waktu.

Namun, dikondisi ekonomi yang melemah di tahun 2020 asumsi tersebut agaknya menjadi tidak terealisasikan, atau dapat diindikasikan bahwa hutang tidak dapat diefisiensikan dengan baik sebagai imbas dari penjualan yang tidak optimal, sebagaimana menurut Sudana (2019) yang mengatakan bahwa pada kondisi ekonomi baik perusahaan yang mempunyai besaran hutang besar mampu menghasilkan laba lebih besar, namun pada kondisi ekonomi lemah penggunaan hutang yang besar akan menghasilkan laba yang lebih kecil. Hal ini merujuk pada biaya bunga akibat pinjaman yang akan tetap menjadi pengurang laba, terlebih penjualan yang tidak optimal menjadi lebih terbatas dalam pencatatan semenjak diterapkannya PSAK 72.

Berdasarkan hal tersebut, penelitian ini akan membahas mengenai pengaruh hutang terhadap laba, dengan spesifik menggunakan debt ratio (DR), return on asset (ROA), dan gross profit margin (GPM) sebagai variabel penelitian untuk mengetahui seberapa besar aktiva perusahaan yang dibiayai oleh hutang, kemampuan perusahaan dalam mengelola modal untuk menghasilkan pengembalian investasi dan marjin keuntungan.

Sektor properti merupakan sektor yang besar karena berkaitan dengan 175 industri, dan berkontribusi terhadap Produk Domestik Bruto (PDB) dalam penyerapan tenaga kerja (Petriella, 2020). Selain itu, sektor properti juga merupakan sektor non-keuangan yang dikaji lebih lanjut sebagai indikator dalam sistem keuangan negara. Kebutuhan akan kreditnya yang besar baik dari sisi perusahaan (kredit investasi) maupun konsumen (kredit konsumsi), sedikit banyak akan mempengaruhi likuiditas perbankan dan stabilitas keuangan negara.

\section{Kajian Literatur \\ Rasio Hutang/Debt Ratio (DR)}

Rasio hutang/debt ratio merupakan rasio yang dapat mengukur tingkat solvabel perusahaan, dengan mengukur perbandingan antara total hutang dan total aset. Semakin besar kemungkinan perusahaan tidak dapat melunasi hutangnya ketika rasio hutangnya tinggi (Hery, 2016). Menurut Riyanto (1998) batas aman proporsi antara hutang dan modal sendiri adalah 1:1, jika jumlah hutang melebihi perbandingan tersebut, terdapat kemungkinan besar bahwa fixed asset/aset tetap didanai oleh hutang. Aset tetap merupakan aset yang bertahan dalam jangka waktu lama, sehingga jika didanai oleh hutang akan beresiko terhadap likuiditas atau kemampuan perusahaan membayar hutang jangka pendek. Selain itu, menurut Frida (2020) perusahaan yang memiliki rasio hutang tinggi akan sulit mendapatkan kelayakan kredit karena dikhawatirkan tidak dapat melunasi hutangnya dengan total aset yang dimiliki.

\section{Nilai Pengembalian atas Aset/Return on Asset (ROA)}

Nilai pengembalian atas aset/return on asset merupakan rasio yang menunjukkan seberapa besar kontribusi aset dalam menciptakan laba bersih. Dengan kata lain, rasio ini digunakan untuk mengukur seberapa besar jumlah laba bersih yang akan dihasilkan dari setiap rupiah dana yang diinvestasikan dalam total aset (Hery, 2016). Menurut Kimmel dkk (2016) ROA merupakan indikator yang dapat menilai profitabilitas perusahaan secara menyeluruh, selain itu ROA adalah formula yang bersumber dari bauran Total Asset Turnover (TATO) dan Net Profit Margin (NPM). 
Dengan menganalisis ROA, secara tersirat dapat diketahui kinerja margin keuntungan bersih dan kontribusi aset terhadap penjualan. Ketika ROA meningkat NPM dan TATO juga terindikasi meningkat, hasil penelitian Liana (2020) mendukung pernyataan tersebut dengan menyebutkan bahwa Total Asset Turnover (TATO) dan Net Profit Margin (NPM) berpengaruh positif dan signifikan terhadap Return on Asset (ROA). Menurut Dyson (dalam Mijić \& Jakšić, 2017) ROA terindikasi baik ketika $\geq 10 \%$.

\section{Marjin Laba Kotor/Gross Profit Margin (GPM)}

Marjin laba kotor/gross profit margin merupakan rasio yang digunakan untuk mengukur besarnya persentase laba kotor atas penjualan, dimana laba kotor diperoleh dari hasil pengurangan antara penjualan bersih dan harga pokok penjualan (Hery, 2016). Melalui GPM akan dapat diketahui kinerja penjualan murni dari aktivitas operasional, dan menunjukkan kemampuan perusahaan untuk mempertahankan penjualan di atas beban pokok penjualannya. Laba kotor merupakan indikator awal dalam pencapaian laba, apabila laba kotor mencapai negatif peluang untuk memperoleh laba setelah biaya lain-lain akan sangat sulit. Jika perusahaan gagal mencapai GPM, secara fundamental bisnisnya merugi (Kimmel dkk., 2016; Prihadi, 2019; Sulindawati dkk., 2017).

Menurut Taillard (2013) marjin laba kotor yang tinggi adalah hal baik, selama perusahaan tidak menaikkan harga terlalu tinggi yang akan membuat konsumen berhenti membeli produknya. Margin laba kotor yang rendah mengindikasikan perusahaan akan sulit mendanai biaya operasional di periode berikutnya, situasi tersebut memungkinkan terjadinya pengurangan tenaga kerja atau bahkan pemberhentian operasional sebagai akibat dari tidak mampu menyediakan fungsi pendukung yang diperlukan untuk mempertahankan operasional inti.

\section{Pengaruh DR Terhadap ROA dan GPM}

Beberapa penelitian menyebutkan bahwa terdapat hubungan atau pengaruh negatif pada DR terhadap ROA (Mijić \& Jakšić, 2017; Ophelia dkk., 2021) maupun GPM (Jusmansyah, 2020; Ophelia dkk., 2021; Yuri dkk., 2021). Lebih lanjut, Dwiantari dkk (2021) juga mengindikasikan adanya pengaruh negatif DR terhadap ROA melalui hasil penelitiannya yang menyebutkan bahwa terdapat pengaruh positif dan signifikan pada leverage terhadap financial distress. Berdasarkan hasil tersebut, diperoleh informasi bahwa semakin besar hutang yang dimiliki semakin besar potensi perusahaan mengalami kesulitan keuangan karena profit yang dihasilkan menurun akibat timbulnya beban bunga dari penggunaan hutang.

Secara lebih spesifik, penelitian yang ditulis oleh Ophelia dkk (2021) menyebutkan bahwa penggunaan hutang baik secara jangka panjang atau jangka pendek mempunyai pengaruh negatif terhadap kinerja keuangan. Melalui penelitian ini, diperoleh informasi bahwa hutang jangka pendek mempuyai pengaruh negatif yang lebih besar dibandingkan hutang jangka panjang terhadap GPM dan ROA.

Beberapa penelitian juga menyebutkan bahwa terdapat pengaruh positif pada DR terhadap ROA (Fauzan \& Mukaram, 2018; Nopitasari dkk., 2018), yang menjelaskan bahwa perusahaan dapat memaksimalkan penggunaan hutang untuk menghasilkan profit. Adapun paradigma penelitian ini tercantum pada Gambar 1.

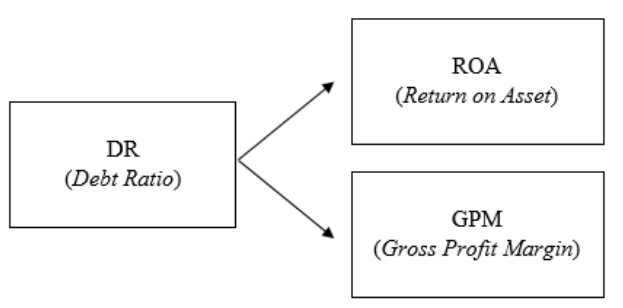

Gambar 1 Paradigma Penelitian 
Berdasarkan paradigma penelitian yang telah dirumuskan, dihasilkan hipotesis atau dugaan sementara hasil penelitian sebagai berikut:

H1 : Terdapat pengaruh negatif dan signifikan DR terdahap ROA pada emiten sektor properti \& real estate untuk periode 2020

H2 : Terdapat pengaruh negatif dan signifikan DR terhadap GPM pada emiten sektor properti \& real estate untuk periode 2020

\section{Metode Penelitian}

Metode yang digunakan dalam penelitian ini adalah metode deskriptif kuantitatif, yang memiliki definisi sebagai metode penelitian yang berfokus pada penggambaran objek berdasarkan fakta-fakta yang dikonversikan menjadi angka untuk memperoleh gambaran yang berlaku secara universal pada situasi dan kondisi tertentu. Adapun teknik pengambilan sampel pada penelitian ini dilakukan dengan probability sampling, yaitu semua populasi memiliki kesempatan yang sama untuk dipilih menjadi sampel (Gursida \& Harmon, 2017). Dari jumlah 78 populasi terpilih sejumlah 67 emiten sektor properti $\&$ real estate sebagai sampel, sehingga diperoleh $21(67$ x $3=201)$ laporan keuangan sebagai kelolaan data. Alasan 11 perusahaan tidak termasuk sebagai sampel adalah karena tidak menyajikan data laporan keuangan yang lengkap pada kuartal 1-3 di tahun 2020.

Metode-metode analisis data yang digunakan pada penelitian ini diantaranya analisis deskriptif, analisis regresi linear, analisis koefisien determinasi, dan uji hipotesis. Analisis deskriptif digunakan untuk memberikan gambaran secara umum tentang variabel yang diteliti. Pada kebanyakan penelitian disajikan nilai minimum, maksimum, rata-rata, dan standar deviasi. Standar deviasi digunakan untuk mengetahui variasi suatu data, semakin kecil standar deviasi maka semakin baik(Gursida \& Harmon, 2017). Adapun analisis regresi linear dapat menunjukkan hubungan kausalitas atau sebab akibat antar variabel, yang dapat digunakan untuk meramal dan memprediksi apa yang terjadi di masa depan dalam rangka meminimalisir tingkat kesalahan dalam pengambilan keputusan (Gursida \& Harmon, 2017; Ismail, 2018).

Disisi lain, koefisien determinasi merupakan persentase total variansi dalam variabel dependent yang dikontribusi oleh variabel indipendent. Analisis ini menjelaskan lebih jauh penafsiran hubungan antar variabel dengan mengkuadratkan nilai koefisien regresi, nilai koefisien determinasi semakin baik apabila mendekati 1, dimana kesalahan yang tak dapat dikendalikan semakin kecil (Lind et al., 2008; Nugroho, 2008). Adapun hipotesis merupakan pernyataan sementara yang akan dijawab berdasarkan data, fakta dan metode yang digunakan dalam penelitian (Gursida \& Harmon, 2017). Uji hipotesis merupakan uji yang didasarkan pada teori probabilitas yang akan menentukan apakah hipotesis diterima karena pernyataan wajar atau ditolak karena pernyataan tidak wajar. Penelitan ilmu sosial pada umumnya menggunakan taraf signifikansi sebesar 0,05 atau $5 \%$, dalam artian semakin nilai signifikan kurang dari 0,05 semakin tinggi tingkat keterwakilan populasi dalam sampel. Selain merujuk pada nilai signifikansi, uji hipotesis juga dapat dilakukan dengan cara membandingkan nilai $\mathrm{t}$ hitung dan $\mathrm{t}$ tabel. Jika $\mathrm{t}$ hitung $>\mathrm{t}$ tabel, maka variabel indipendent mempunyai pengaruh yang signifikan.

\section{Hasil dan Pembahasan Analisis Deskriptif}

Tabel 1 menampilkan hasil analisis deskriptif yang menyajikan nilai minimum, maksimum, mean, dan standar deviasi. Lebih lanjut, dipaparkan juga mengenai hasil analisis deskriptif per variabel yang diteliti dalam penelitian ini.

Tabel 1 Hasil Analisis Deskriptif

\begin{tabular}{l|c|r|r|r|r}
\hline & $\mathrm{N}$ & \multicolumn{1}{|c|}{ Minimum } & Maximum & \multicolumn{1}{c|}{ Mean } & \multicolumn{1}{c}{ Std. Deviation } \\
\hline DR & 201 & .0012 & .8119 & .347259 & .2017710 \\
\hline ROA & 201 & -.0861 & .0631 & -.000883 & .0215804 \\
\hline GPM & 201 & -.6883 & 1.6725 & .474818 & .2640033 \\
\hline Valid N (listwise) & 201 & & & & \\
\hline
\end{tabular}


Berdasarkan Tabel 1, diketahui nilai rata-rata variabel DR diketahui sebesar 0.347259 atau $34,72 \%$, berdasarkan persentase tersebut proporsi pendanaan pada emiten sektor properti lebih banyak mengandalkan modal sendiri. Dengan besaran rata-rata tersebut, dapat diindikasikan bahwa kelolaan hutang emiten sektor properti masih tergolong aman dan baik karena dibawah 50\% sebagaimana dijelaskan dalam Riyanto (1998) yang mengatakan bahwa besaran modal asing dalam keadaan apapun jumlahnya tidak boleh melebihi 1:1 terhadap modal sendiri.

Diketahui nilai rata-rata variabel ROA adalah sebesar -0.000883. Dari nilai tersebut dapat diindikasikan bahwa dari penempatan Rp 1 pada aset, diperoleh kerugian sebesar $0.08 \%$ pada emiten sektor properti. Hasil ini cukup menjadi jawaban atas pengaruh lemahnya ekonomi terhadap nilai pengembalian atas investasi, dimana profit yang dihasilkan tidak cukup sebanding atas jumlah modal yang diinvestasikan pada aset. Sedangkan nilai rata-rata variabel gross profit margin adalah sebesar 0.474818. Dari nilai tersebut dapat diindikasikan bahwa dari total penjualan, diperoleh marjin keuntungan sebesar $47,48 \%$ pada perusahaan sektor properti.

Tabel 2 Hasil Analisis Deskriptif DR

\begin{tabular}{l|r|r|r|r}
\hline & \multicolumn{1}{|c|}{$\mathrm{N}$} & \multicolumn{1}{c}{ Minimum } & Maximum & \multicolumn{1}{l}{ Mean } \\
\hline DR Q1 & 67 & .0012 & .7706 & .349334 \\
\hline DR Q2 & 67 & .0023 & .7917 & .345829 \\
\hline DR Q3 & 67 & .0021 & .8119 & .346611 \\
\hline
\end{tabular}

Analisis deskriptif debt ratio dari kuartal ke kuartal yang ditampilkan pada Tabel 2 menunjukkan rata-rata yang tidak terlalu mengalami perubahan signifikan. Hasil ini mengindikasikan bahwa sebagian besar emiten sektor properti menahan untuk melakukan ekspansi usaha dengan menggunakan hutang. Adapun emiten yang memiliki nilai proporsi hutang paling tinggi pada kuartal 1-3 yaitu PT Bliss Properti Indonesia Tbk yang mengalami peningkatan penggunaan hutang di kisaran 1 sampai $2 \%$, namun diketahui tidak diiringi dengan peningkatan pada aset. Dengan hasil ini, diketahui bahwa PT Bliss Properti Indonesia Tbk mengalami kerugian, dan peningkatan penggunaan hutang disinyalir digunakan untuk menutup biaya operasional bukan untuk melakukan ekspansi. Kondisi tersebut semakin mendukung pendapat Sudana dkk (2019) yang mengakatan bahwa pada kondisi ekonomi lemah, penggunaan hutang yang besar akan menghasilkan laba yang lebih kecil.

Dilansir lebih lanjut melalui laporan keuangan tahun 2020, PT Bliss Properti Indonesia Tbk lebih fokus untuk menginvestasikan modal sebagai properti komersial berupa pusat perbelanjaan dan hotel. Seperti yang diketahui, di tahun 2020 kedua segmen tersebut mengalami kendala dalam menjalankan operasionalnya.

Tabel 3 Hasil Analisis Deksriptif ROA

\begin{tabular}{l|r|r|r|l}
\hline & \multicolumn{1}{|c|}{$\mathrm{N}$} & \multicolumn{1}{c|}{ Minimum } & Maximum & \multicolumn{1}{c}{ Mean } \\
\hline ROA Q1 & 67 & -.0622 & .0574 & -.000545 \\
\hline ROA Q2 & 67 & -.0423 & .0400 & -.000754 \\
\hline ROA Q3 & 67 & -.0861 & .0631 & -.001347 \\
\hline
\end{tabular}

Analisis deskriptif return on asset dari kuartal ke kuartal yang ditampilkan pada Tabel 3 menunjukkan rata-rata yang tidak terlalu mengalami perubahan signifikan. Hasil ini mengindikasikan bahwa sebagian besar emiten sektor properti di tahun 2020 sulit mengoptimalkan aset untuk menghasilkan keuntungan. Adapun emiten yang memiliki nilai pengembalian atas aset paling tinggi pada kuartal 1-3 pun belum dapat diindikasikan baik dalam pengembalian atas investasi menurut Dyson (dalam Mijic \& Jaksic, 2017) yang menyatakan bahwa ROA terindikasi baik ketika $\geq 10 \%$.

Emiten yang dapat memaksimalkan laba dengan sangat baik dari tiap kuartal yaitu PT Lippo Cikarang Tbk untuk kuartal-1, PT Roda Vivatex Tbk untuk kuartal-2, dan PT Jaya Real Property Tbk untuk kuartal-3, diketahui ketiganya memiliki fokus pada jenis kelolaan properti dalam struktur yang berbeda-beda. Diketahui segmen properti residensial berkontribusi paling besar terhadap pendapatan PT Lippo Cikarang Tbk dengan jumlah proporsi terhadap pendapatan sebesar $68,61 \%$, sedangkan pada 
PT Roda Vivatex Tbk diketahui segmen sewa perkantoran merupakan segmen yang berkontribusi paling besar terhadap pendapatan PT Roda Vivatex Tbk dengan jumlah proporsi terhadap pendapatan sebesar 93,96\%. Adapun pada PT Jaya Real Property Tbk kontribusi paling besar terhadap pendapatan diperoleh dari segmen penjualan tanah dengan jumlah proporsi terhadap pendapatan sebesar 44,59\%.

Melalui ringkasan pendapatan ketiga emiten diatas, dapat ditarik kesimpulan bahwa di tahun 2020 sektor properti \& real estate memiliki kesempatan untuk memaksimalkan aset menjadi profit, baik melalui properti residensial maupun maupun komersial. Dari sisi properti residensial, PT Lippo Cikarang Tbk mencerminkan pengaruh dari adanya penurunan suku bunga KPR yang berdampak pada meningkatnya penjualan rumah sebesar 53,36\% dari tahun sebelumnya. Sedangkan dari sisi properti komersial, PT Roda Vivatex Tbk dan PT Jaya Real Property dapat memaksimalkan penggunaan aset untuk menghasilkan profit, meskipun terjadi penurunan pendapatan dibandingkan tahun sebelumnya.

Tabel 4 Hasil Analisis Deskriptif GPM

\begin{tabular}{l|r|r|r|r}
\hline & \multicolumn{1}{|c|}{$\mathrm{N}$} & \multicolumn{1}{c}{ Minimum } & \multicolumn{1}{c}{ Maximum } & \multicolumn{1}{c}{ Mean } \\
\hline GPM Q1 & 67 & -.0613 & 1.5329 & .51125 \\
\hline GPM Q2 & 67 & -.6883 & 1.6724 & .44305 \\
\hline GPM Q3 & 67 & -.2550 & 1.6451 & .47015 \\
\hline
\end{tabular}

Analisis deskriptif gross profit margin dari kuartal ke kuartal yang ditampilkan pada Tabel 4 menunjukkan perubahan rata-rata sebesar $-6,82 \%$ dari kuartal-1 ke kuartal-2, dan perubahan rata-rata sebesar 2,71\% dari kuartal-2 ke kuartal-3. Hasil ini mengindikasikan bahwa emiten properti sempat menurunkan harga jual/sewa, namun kemudian menaikkan harga kembali.

PT Metropolitan Kentjana Tbk sebagai emiten yang dapat memaksimalkan marjin keuntungan kotor di tiap kuartal tahun 2020, merupakan perusahaan yang lebih fokus terhadap kelolaan properti komersial berupa pusat perbelanjaan, pusat perkantoran, apartemen, dan hotel yang berkontribusi terhadap pendapatan sebesar $76 \%$ dibandingkan kelolaan properti residensial. Meskipun pendapatan sewa merupakan penyumbang terbesar dalam struktur pendapatan di tahun 2020, hasil tersebut menurun sebesar 31,23\% dan juga mempengaruhi perolehan marjin keuntungan yang menurun sebesar 10,67\% dari tahun sebelumnya. Hasil tersebut mengindikasikan bahwa PT Metropolitan Kentjana menurunkan harga jual demi tercapainya volume penjualan yang tinggi. Tindakan ini merupakan salah satu upaya dari manajemen keuangan dalam menyeimbangkan arus kas, karena dalam keadaan ekonomi lemah penggunaan dana internal yang salah satunya bersumber dari hasil pendapatan akan lebih aman dibandingkan menggunakan pinjaman yang menimbulkan beban bunga.

\section{Analisis Regresi Linear}

Tabel 5 menyajikan hasil analisis koefisien regresi variabel $\mathrm{X}(\mathrm{DR} /$ debt ratio) terhadap variabel $\mathrm{Y} 1$ (ROA/return on asset). Sedangkan Tabel 6 menyajikan hasil analisis koefisien regresi variabel $\mathrm{X}$ (DR/debt ratio) dan variabel Y2 (GPM/gross profit margin).

Tabel 5 Hasil Analisis Regresi DR Terhadap ROA

\begin{tabular}{l|c|r|r|r|r|r}
\hline \multirow{2}{*}{ Model } & & \multicolumn{2}{|c|}{$\begin{array}{c}\text { Unstandardized } \\
\text { Coefficients }\end{array}$} & $\begin{array}{c}\text { Standardized } \\
\text { Coefficients }\end{array}$ & \multirow{2}{*}{} \\
\cline { 3 - 6 } & & $\mathrm{B}$ & Std. Error & Beta & $\mathrm{t}$ & \multicolumn{1}{c}{ Sig. } \\
\hline 1 & (Constant) & .012 & .003 & & 4.127 & .000 \\
\cline { 2 - 6 } & DR & -.037 & .007 & -.342 & -5.127 & .000 \\
\hline
\end{tabular}

a Dependent Variable: ROA

Berdasarkan Tabel 5, diperoleh nilai a/konstanta sebesar 0,012 yang menunjukkan nilai return on asset yang dapat diperoleh ketika debt ratio sama dengan nol. Lalu diperoleh nilai b sebesar $-0,342$ yang merupakan nilai koefisien regresi variabel debt ratio. Dari kedua nilai tersebut diperoleh 
persamaan regresi $\mathrm{Y}=0,012-0,342 \mathrm{X}$, yang dapat diinterpretasikan menjadi return on asset diprediksi akan turun sebesar 0,342 atau 34,2\% jika debt ratio dinaikkan 1 poin.

Tabel 6 Hasil Analisis Regresi DR Terhadap GPM

\begin{tabular}{l|c|r|r|r|r|r}
\hline \multirow{2}{*}{ Model } & & \multicolumn{2}{|c|}{$\begin{array}{c}\text { Unstandardized } \\
\text { Coefficients }\end{array}$} & $\begin{array}{c}\text { Standardized } \\
\text { Coefficients }\end{array}$ & & \\
\cline { 3 - 6 } & & $\mathrm{B}$ & Std. Error & Beta & $\mathrm{t}$ & \multicolumn{1}{c}{ Sig. } \\
\hline 2 & (Constant) & .609 & .036 & & 17.112 & .000 \\
\cline { 2 - 7 } & DR & -.386 & .089 & -.295 & -4.351 & .000 \\
\hline
\end{tabular}

a Dependent Variable: GPM

Berdasarkan Tabel 6, diperoleh nilai a/konstanta sebesar 0,609 yang menunjukkan nilai gross profit margin yang dapat diperoleh ketika debt ratio sama dengan nol. Lalu diperoleh nilai b sebesar 0,295 yang merupakan nilai koefisien regresi variabel debt ratio. Dari kedua nilai tersebut, diperoleh persamaan regresi $\mathrm{Y}=0,609-0,295 \mathrm{X}$, yang dapat diinterpretasikan menjadi gross profit margin diprediksi akan turun sebesar 0,295 atau 29,5\% jika debt ratio dinaikkan 1 poin.

\section{Analisis Koefisien Determinasi}

Nilai koefisien determinasi dapat diperoleh dengan mengkuadratkan nilai koefisien regresi, sehingga diperoleh nilai R square sebesar 11,7\%, untuk ROA dan 8,7\% untuk GPM. Kedua nilai tersebut dapat diinterpretasikan menjadi DR berkontribusi terhadap ROA sebesar 11,7\% dan DR berkontribusi terhadap GPM sebesar $8,7 \%$.

\section{Uji Hipotesis}

Uji hipotesis dapat dilakukan dengan melihat nilai signifikan dan t hitung pada Tabel 5 dan 6 . Adapun $\mathrm{t}$ tabel yang dijadikan acuan perbandingan $\mathrm{t}$ hitung, dapat diperoleh melalui rumusan berikut: $\mathrm{t}$ tabel $=$ $(\alpha ; \mathrm{n}-\mathrm{k}-1$ atau df $)=(0,05 ; 199)=1,6525$. Dari Tabel 5, diperoleh nilai t 5,127 (nilai menjadi absolut) $>$ dari nilai t tabel 1,6525. Dengan hasil ini, dinyatakan bahwa $\mathrm{H}_{1}$ diterima dengan pernyataan hipotesis terdapat pengaruh negatif dan signifikan pada DR terhadap ROA. Hasil akhir yang sama juga dapat diperoleh dengan merujuk pada nilai signifikan yang lebih kecil dari taraf signifikansi $(0.000<0,05)$.

Sedangkan dari Tabel 6, diperoleh nilai t 4,351 (nilai menjadi absolut) $>$ dari nilai t tabel 1,6525. Dengan hasil ini, dinyatakan bahwa $\mathrm{H}_{2}$ diterima dengan pernyataan hipotesis terdapat pengaruh negatif dan signifikan pada DR terhadap GPM. Hasil akhir yang sama juga dapat diperoleh dengan merujuk pada nilai signifikan yang lebih kecil dari taraf signifikansi $(0.000<0,05)$.

\section{Pengaruh Debt Ratio Terhadap Return on Asset}

Berdasarkan Tabel 5 diperoleh nilai signifikan 0,000 yang lebih kecil dari taraf signifikansi 0,05, dan t hitung $-5,172$ atau 5,172 (menjadi absolut) yang lebih kecil dari t tabel 1,6525. Secara bersama-sama nilai signifikan dari kedua metode tersebut menunjukkan bahwa $\mathrm{H} 1$ diterima "terdapat pengaruh negatif dan signifikan pada DR dan ROA emiten sektor properti dan real estate untuk periode 2020". Hasil penelitian ini sejalan dengan penelitian yang dilakukan oleh Ophelia (2021) dan Mijic \& Jaksic (2017) yang menyebutkan bahwa terdapat hubungan atau pengaruh negatif pada hutang dan profitabilitas.

Adapun besar pengaruh ditentukan dari hasil uji koefisien determinasi atau $\mathrm{R}^{2}$ menunjukan nilai sebesar $11,7 \%$, yang dapat diinterpretasikan bahwa debt ratio mempunyai pengaruh terhadap return on asset sebesar $11,7 \%$, sedangkan 88,3\% lainnya dipengaruhi oleh variabel lain yang dapat dijadikan bahan penelitian lanjutan. Untuk menganalisis lebih lanjut mengenai pengaruh DR terhadap ROA, dilakukan analisis terhadap emiten yang memiliki nilai DR lebih rendah dari rata-rata DR kuartal 1-3 (yaitu 0,347259). Diperoleh sebanyak 35 emiten yang memiliki rasio hutang kurang dari 0,34\% dari kuartal 1-3 tahun 2020, lebih lanjut diketahui bahwa ROA pada 32 emiten dipengaruhi oleh DR, dimana kenaikan pada DR akan menyebabkan penurunan ROA, dan penurunan DR akan menyebabkan kenaikan pada ROA. Hal ini disinyalir karena menambah kelolaan hutang sebagai upaya ekspansi akan sulit dilakukan pada perekonomian yang lemah dimana daya serap pasar atau penjualan sedang tidak 
optimal, menambah hutang hanya akan semakin mengurangi profit karena terdapat beban bunga yang menyertainya.

Adapun emiten yang dapat meningkatkan ROA dari kuartal ke kuartal di tahun 2020 diantaranya PT Armidian Karyatama Tbk, PT Puradelta Lestari Tbk, PT Duta Pertiwi Tbk, PT Metropolitan Land Tbk, PT Plaza Indonesia Realty Tbk, PT Roda Vivatex Tbk, dan PT Suryamas Dutamakmur Tbk. Jika dilihat lebih lanjut dari struktur pendapatan, 4 dari 5 emiten tersebut banyak memperoleh pendapatan melalui penjualan properti dan real estate, seperti penjualan tanah, gudang, rumah, bangunan dll. Melalui analisis ROA terdapat emiten yang diketahui memiliki tren serupa dengan kelima emiten yang disebutkan diatas, namun memiliki nilai penjualan yang jauh leibh rendah dibandingkan nilai laba bersih setelah pajak secara kuartal ke kuartal. Kondisi tersebut mengindikasikan adanya upaya manajemen untuk membuat laba yang rugi menjadi terlihat lebih baik saat penghitungan laba bersih setelah pajak dengan melakukan penambahan modal, menjual beberapa kelolaan aset, atau mengandalkan kenaikan nilai dari deposito. Selain menganalisis nilai ROA, investor juga perlu untuk melihat nilai penjualan untuk melihat adanya kemungkinan tersebut

\section{Pengaruh Debt Ratio Terhadap Gross Profit Margin}

Berdasarkan Tabel 6 diperoleh nilai signifikan 0,000 yang lebih kecil dari taraf signifikansi 0,05, dan t hitung $-4,351$ atau 4,351 (menjadi absolut) yang lebih kecil dari t tabel 1,6525. Secara bersama-sama nilai signifikan dari kedua metode tersebut menunjukkan bahwa $\mathrm{H}_{2}$ diterima "terdapat pengaruh negatif dan signifikan pada DR dan GPM emiten sektor properti \& real estate untuk periode 2020". Hasil penelitian ini sejalan dengan penelitian yang dilakukan oleh Ophelia (2021), Jumansyah (2020), dan Yuri dkk (2021) yang menyebutkan bahwa terdapat pengaruh negatif pada hutang dan profitabilitas.

Adapun besar pengaruh ditentukan dari hasil uji koefisien determinasi atau $\mathrm{R}^{2}$ menunjukan nilai sebesar $8,7 \%$. Maka dapat disimpulkan bahwa debt ratio mempunyai pengaruh terhadap gross profit margin sebesar $8,7 \%$, sedangkan 91,3\% lainnya dipengaruhi oleh variabel lain yang dapat dijadikan bahan penelitian lanjutan. Untuk menganalisis lebih lanjut mengenai pengaruh DR terhadap ROA, dilakukan analisis terhadap emiten yang memiliki nilai DR lebih rendah dari rata-rata DR kuartal 1-3 (yaitu 0,347259). Diperoleh sebanyak 35 emiten yang memiliki rasio hutang kurang dari $0,34 \%$ dari kuartal 1-3 tahun 2020, lebih lanjut diketahui bahwa GPM pada 26 emiten dipengaruhi oleh DR, dimana kenaikan pada DR akan menyebabkan penurunan GPM, dan penurunan DR akan menyebabkan kenaikan pada GPM. Pengaruh negatif DR terhadap GPM juga serta merta membuat pengaruh negatif terhadap ROA pada 22 emiten. Hal ini menjelaskan bahwa ketika marjin keuntungan menurun, pengembalian atas investasi juga menurun.

Jika dilakukan analisis lebih lanjut pada lima emiten yang dapat meningkatkan ROA dari kuartal ke kuartal di tahun 2020 (sebagaimana disebutkan dalam sub bab sebelumnya), diketahui bahwa GPM pada kelima emiten tersebut menurun dari tahun sebelumnya. Meskipun terjadi penurunan GPM, setidaknya kelima emiten tersebut dapat mempertahankan nilai penjualan di atas beban pokok penjualannya. Kinerja manajemen pada kelima emiten tersebut juga tergolong baik, karena mampu menghasilkan ROA yang terus meningkat, sehingga pada keadaan ekonomi yang stabil kelima emiten tersebut diprediksi dapat berkinerja lebih baik berdasarkan pendekatan fundamental.

\section{Kesimpulan}

Besaran struktur hutang tersebut dapat diindikasikan aman dan baik karena dibawah $50 \%$ dari total modal. Lalu di tahun 2020, emiten sektor properti \& real estate menghasilkan kerugian sebesar 0,08\% dari setiap penempatan Rp 1 pada aset, dengan perolehan marjin keuntungan sebesar 47,48\% dari total laba kotor. Adapun pengaruh debt ratio terhadap return on asset dan gross profit margin dinyatakan negatif dan signifikan dengan besaran pengaruh sebesar 11,7\% terhadap return on asset dan 8,7\% terhadap gross profit margin. Bagi investor yang berminat melalukan investasi di sektor properti real estate disarankan untuk melihat juga nilai penjualan saat menganalisis ROA untuk mengetahui lebih lanjut apakah ROA banyak dikontribusi oleh kinerja emiten berdasarkan penjualan atau sekedar upaya manajemen untuk memperhalus laba bersih setelah pajak yang diperoleh dari tambahan modal disetor, penjualan aset, dan pengembalian atas deposito. Selain itu nilai GPM yang tidak meningkat signifikan tidak mengindikasikan emiten berkinerja buruk, karena setidaknya hal tersebut merupakan upaya 
manajemen untuk tetap menghasilkan pendapatan di atas beban pokok penjualan, terlebih di tahun 2020 penjualan tidak dapat optimal karena dampak dari perekonomian yang melemah. Pada dasarnya perolehan GPM tidak selalu mempunyai tren yang meningkat karena terdapat bebagai kondisi dimana perusahaan tidak bisa melakukannya, misalnya karena terdapat persaingan dengan kompetitor sehingga membuat perusahaan tidak dapat memasang harga yang terlalu tinggi, dan kondisi dimana perusahaan mengupayakan volume penjualan supaya arus kas terjaga, dan terdapat berbagai faktor atau kondisi lainnya yang berhubungan dengan menjaga stabilitas perusahaan.

\section{Daftar Pustaka}

Departemen Statistik BI. (2020a). Perkembangan Properti Komersial (PPKOM). https://www.bi.go.id/id/publikasi/laporan/Documents/PPKom_Triwulan_IV_2020.pdf

Departemen Statistik BI. (2020b). Survei Harga Properti Residensial. https://www.bi.go.id/id/publikasi/laporan/Documents/SHPR-Triwulan-IV-2020.pdf

Dwiantari, R. A., Gede, L., \& Artini, S. (2021). The Effect of Liquidity , Leverage, and Profitability on Financial Distress ( Case Study of Property and Real Estate Companies on the IDX 20172019 ). American Journal of Humanities and Social Sciences Research (AJHSSR), 5(1), 367-373. www.ajhssr.com

Fauzan, M. R., \& Mukaram, M. (2018). Pengaruh Struktur Modal Terhadap Profitabilitas (Studi Pada Perusahaan Pertambangan Yang Terdaftar di Bursa Efek Indonesia Periode 2011-2015). Jurnal Riset Bisnis Dan Investasi, 3(3), 89. https://doi.org/10.35697/jrbi.v3i3.948

Gursida, H., \& Harmon. (2017). Metode Penelitian Bisnis dan Keuangan. Paspi.

Hery. (2016). Analisis Laporan Keuangan. Grasindo.

Ismail, F. (2018). Statistika Untuk Penelitian Pendidikan dan Ilmu-Ilmu Sosial. Kencana.

Jusmansyah, M. (2020). Analisis Pengaruh Manajemen Modal Kerja dan Leverage Terhadap Gross Profit Margin. Jurnal Akuntansi Dan Keuangan, 9(1), 32-48.

Kimmel, P. D., Weygand, J. J., \& Kieso, D. E. (2016). Financial Accounting: Tools for Business Decision Making 8th. John Wiley \& Sons.

Liana, T. M. M. (2020). Analisis Faktor-Faktor yang Mempengaruhi Nilai Perusahaan dengan ROA Sebagai Variabel Intervening (Studi Pada Perusahaan Manufaktur Food and Beverages yang Terdaftar di BEI Tahun 2015-2017). Jurnal Ilmiah Maksitek, 5(3), 140-149.

Lind, D. A., Marchal, W. G., \& Wathen, S. A. (2008). Statistical Techniques in Business and Economics with Global Data Sets (13th ed.). Salemba Empat.

Mijić, K., \& Jakšić, D. (2017). Indebtedness of Enterprises and Profitability Improvement. Strategic Management, 22(2), 36-40.

Nopitasari, H., Tiorida, E., \& Sarah, I. S. (2018). Pengaruh Financial Leverage Terhadap Kinerja Keuangan (Studi Pada Perusahaan Properti dan Real Estate yang Terdaftar di Bursa Efek Indonesia Periode 2011-2015). Jurnal Riset Bisnis Dan Investasi, 3(3), 45. https://doi.org/10.35697/jrbi.v3i3.944

Nugroho, S. (2008). Dasar-dasar Metode Statistika. Grasindo.

Ophelia, A., Min, S., Aliou, D. M., Farhana, A., George, N., Justice, G., \& Philip, A. S. (2021). The impact of Debt Financing on Performance of Small and Medium Enterprises in Ghana. International Journal of Advanced Engineering Research and Science, 8(7), 193-201. https://doi.org/10.22161/ijaers.87.23

Prihadi, T. (2019). Analisis Laporan Keuangan Konsep dan Aplikasi. Gramedia.

Puspitasari, R., Yanfitri, \& Prastowo, N. J. (2020). Transmisi Kebijakan Moneter di Indonesia Melalui Jalur Balance Sheet: Dampak Kondisi Domestik dan Eksternal. In F. Mochtar, Sahminan, \& A. S. Budiman (Eds.), Transmisi Kebijakan Moneter di Indonesia Menuju Era Ekonomi Digital (pp. 91-132). Bank Indonesia. https://www.bi.go.id/id/publikasi/kajian/Documents/TransmisiKebijakan-Moneter-di-Indonesia-Menuju-Era-Ekonomi-Digital.pdf

Sudana, I. M. (2019). Manajemen Keuangan Teori dan Praktik. Airlangga University Press.

Sulindawati, N. L., Yuniarti, G. A., \& Purnamawati, I. G. A. (2017). Manajemen Keuangan: Sebagai Dasar Pengambilan Keputusan Bisnis. Rajawali Press. 
Taillard, M. (2013). Corporate Finance for Dummies. John Wiley \& Sons.

Yuri, R., Fatonah, S., \& Meilisa, R. (2021). Pengaruh Current Ratio (CR) dan Debt to Equity Ratio (DER) Terhadap Gross Profit Margin (GPM) (Studi Kasus pada Perusahaan Manufaktur SUbsektor Farmasi yang Terdaftar Di Bursa Efek Indonesia). Jurnal Bina Bangsa Ekonomika, 14(1), 172-181.

\section{*Email korespondensi:}

robiiah.almauunah.abs417@polban.ac.id 